\title{
In Search of Relevance: The Advisory Roles of Political Scientists in Spain
}

\author{
José Real-Dato
}

\subsection{INTRODUCTION}

The idea that political science should be socially relevant has always been present during the development of the discipline (Easton, 1969; Ricci, 1984). Producing knowledge that is useful for society has been perceived by many not only as an ethical responsibility, but also as a way of granting social recognition to political science and of reinforcing the legitimacy of the discipline, both internally-compared to other disciplines-and externally - with respect to potential users of such knowledge and the general public. However, many authors have suggested that social engagement needs to be subordinated to the cultivation of the highest epistemic standards and have therefore criticized those who prioritize applicability over scientific rigour. ${ }^{1}$

${ }^{1}$ The clearest example of such debate in this century has been the controversy raised by the 'Perestroika movement' in political science (in the early 2000s) and the subsequent debate

J. Real-Dato $(\bowtie)$

University of Almería, Almería, Spain

e-mail: jreal@ual.es

(C) The Author(s) 2022

M. Brans, A. Timmermans (eds.), The Advisory Roles of Political

Scientists in Europe, https://doi.org/10.1007/978-3-030-86005-9_12 
The question of how political science could be more relevant to society has become even more pressing in recent years (Flinders, 2013; Stoker et al., 2015; Real-Dato \& Verzichelli, 2021). The impact of research has become a criterion for its evaluation, and for the allocation of research funds, in many countries (Bandola-Gill et al., 2021, 35-63). This forces political scientists to demonstrate that their work not only contributes to expanding our understanding of the political and social world, but also that this better understanding can in some way help to change that world.

One of the ways in which political scientific knowledge is more likely to have an actual impact is by channelling it into the political process. Providing political or policy advice does not guarantee that such advice will have a direct, immediately visible impact on political actors' behaviour or decisions-knowledge 'silver bullets' are a rare phenomenon, particularly in policy-making processes (Weiss, 1980). However, the proactive involvement of political scientists in advisory tasks may make political science more relevant in other ways (Flinders, 2013). Advice recipients may value political science knowledge because it can provide additional legitimacy to policy decisions, or due to its mere enlightening function (Weiss, 1977). Moreover, the simple act of providing advice is important as such in order to enhance the visibility of political science vis-à-vis other competing disciplines in the policy and political advice market.

Assuming the importance of the advisory role of political scientists for the relevance of the discipline and identifying those factors that explain why individuals engage in such activities may help identify ways in which the social relevance of the discipline can be enhanced. This is particularly important in countries like Spain, where the institutionalization of political science as an academic discipline came relatively late (Jerez-Mir, 2010; Jerez \& Luque, 2016; Ortega-Ruiz, et al., 2021).

Therefore, this chapter analyses the involvement of Spain's academic political scientists in political and policy advisory tasks, as well as the factors that account for such involvement. It does so by using data from the ProSEPS COST Action survey (see Chap. 3) collected from political scientists working in Spanish academic institutions in the year 2018.

The chapter is structured as follows. First, I provide the general background to the phenomenon in question, by describing both the

between Flyvbjerg and the critics of his 'phronetic approach' to social science (Flyvbjerg, 2001, 2006; Flyvbjerg et al., 2012; Laitin, 2003; Monroe, 2005; Schram \& Caterino, 2006). However, such concerns can be traced back even further in time (Ricci, 1984). 
contextual opportunities and limitations affecting the demand and supply of policy and political advice in Spain. I then formulate the research questions that will guide the empirical analysis and elaborate a number of theoretical propositions (hypotheses) that could explain the frequency and causes of political scientists' engagement in policy advice activities. Subsequently, I introduce the data used in the analysis, which takes up the rest of the chapter. The analysis is divided into two sections: the first section presents the main features of the advisory roles adopted by political scientists in Spain; the second section examines those factors explaining their involvement in advisory tasks. The chapter ends with a reflection on the contribution of such involvement to the relevance of political science in the next future.

\subsection{Opportunities And Limitations on Advice By Political SCIENTists in SPAin}

The ability of academic political science to enhance its social relevance through the provision of policy and political advice depends on both supply and demand factors. On the demand side, political science advice must be sought by actors participating in political processes. Although no systematic evaluation of such demand in Spain has been conducted, the analysis of the context of opportunity for political science advice in the Spanish political system may provide some clues as to the entity of demand.

This context of opportunity is closely linked to the characteristics of the political (and policy) advisory system. On the one hand, the politically decentralized structure of the Spanish state (Magone, 2008) potentially favours the opportunities for such advice provision, at least in terms of the multiplication of the decision-making venues. Each of the seventeen regions (Comunidades Autónomas) has its own government, parliament and public administration, deciding on (often through exclusive powers) and managing an extensive number of policy subjects, including key areas such as health, education, social policy, territorial development or tourism.

Policy making in today's Spain mainly fits the neo-pluralist model, with elements of neo-corporatist dynamics witnessed in several policy areas (particularly those comprising policies with an economic component) (Molins \& Medina, 2019). Therefore, public policies are currently being developed in a multiplicity of sectoral subsystems whose components and internal patterns of interaction (consensual vs. conflictual) differ. 
Sometimes these subsystems may be of a multilevel character (involving national and regional arenas and actors), while others are restricted to one specific political level. Within these subsystems, therefore, there may be several types of client interested in acquiring political science knowledge at any given moment: 1) decision-makers (either in parliaments, governments or public administrations; 2) arm's-length public advisory bodies (i.e. advisory bodies, either permanent or ad-hoc, that are not situated directly within the hierarchical structure of the government) (OECD, 2017: 96); 3) political parties; 4) think tanks; 5 ) interest groups and other private organizations. Therefore, Spanish politics, and particularly the decentralized characteristics of the state, offers, at least potentially, substantial opportunities for engaging in the political process by providing advice in this myriad of decision-making situations.

In addition, changes in Spanish politics in recent decades have increased the opportunities to use political science knowledge among political agents, as well as the receptivity of said agents to such knowledge. On the one hand, over the last two decades Spain's public administrations have (slowly) placed greater emphasis on performance, quality and evaluation (Alba \& Navarro, 2011; Parrado, 2008). These are all areas where political scientists specialised in public administration can make an important contribution. One example of this was the creation in 2007 of the AEVAL (Agencia Estatal para la Evaluación de Politicas Públicas y Calidad en los Servicios Públicos - State Agency for Policy Evaluation and Public Services Quality). ${ }^{2}$ This Agency can be considered one of the flagships of this performance and evaluation movement within Spain's public administration, and academic political scientists played an important role in its inception.

Moreover, the advent of the economic crisis in the late 2000s has resulted in political science becoming more visible. ${ }^{3}$ The crisis triggered a number of political consequences which changed the existing political landscape: a crisis of confidence in political institutions (both national and European); increased politicization of public opinion and electoral volatility; a reconfiguration of the party system, which was transformed from a two-party system to a polarized, multiparty system; and increased governmental instability, particularly at national level (Montabes \& Martínez,

\footnotetext{
${ }^{2}$ In 2017 it was re-named the Institute for Public Policy Evaluation (Instituto para la Evaluación de Politicas Públicas).

${ }^{3} 76.4$ per cent of the respondents to the ProSEPS survey in Spain stated that the impact of political scientists on public debate has increased since 2009.
} 
2019; Muro \& Lago, 2020; Reniu, 2018). In addition, there has also been the territorial and constitutional crisis provoked by the attempted secession of Catalonia in 2017. This context has boosted the demand for political science knowledge, particularly from the mass media, to help make sense of all these changes, and eventually to propose alternatives.

However, this picture would not be complete without an examination of the limitations faced by those academic political scientists who wish to engage as advisors. Firstly, the receptivity of potential users to knowledge provided by academic political scientists is limited by the competing sources of advice that exist. Political science is at a disadvantage compared to other 'neighbouring' disciplines, particularly law and economics. Legal knowledge has traditionally occupied a key position in Spain's political and policy advice system. This importance is accounted for not only by the key structural role played by formal regulations in the functioning of any state, but also by the inheritance of a legalistic tradition common to countries where public administration developed on the basis of the principles of the Napoleonic State (Alba \& Navarro, 2011; Ongaro, 2010; Parrado, 2008). This tradition has promoted an administrative (and political) culture mainly focused on normative compliance, while efficiency and quality of service have generally been considered of secondary importance (OECD, 2015 ). This is also evident in public administration recruitment procedures, where knowledge of the law is of key importance in public exams, while political science subjects are of marginal importance even in those areas of the civil service specialised in public management. Consequently, this legalistic culture has left limited room for certain standard avenues for the entry of political science knowledge into the political system-such as advice on policy diagnostics, strategy or design, public management instruments and reform, policy evaluation, or even major institutional or constitutional reforms (electoral or territorial).

Despite the fact that the above-mentioned modernization of Spain's public administration in recent years - with a greater emphasis placed on performance, quality of public policy and public management-has considerably bolstered the opportunities for political scientists to engage in policy advisory activities, they by no means command exclusive knowledge of these subjects. Political scientists wishing to provide advice on these areas have to compete with other larger, more well-established academic disciplines such as economics, sociology, or even psychology. Economists have had two major competitive advantages over political scientists. Firstly, economics as an academic discipline was institutionalized much earlier, in 
the early nineteenth century in fact (Martín Rodríguez, 1989). Secondly, the state's increased intervention in the management of Spain's economy and trade during both the nineteenth and, in particular, the twentieth centuries boosted the demand for economic knowledge from the country's government and public administration. This demand was institutionalized in the 1930s, with the creation of a specific civil service Corps of State Trade Technicians, followed in the 1950s by the establishment of the Corps of State Economists (ATCEE, 2020). In sum, the leading role in the modernization of public management, and the introduction of quality assurance and policy evaluation techniques in public administration in Spain, can be mainly attributed to civil servants with a background in economics or law. ${ }^{4}$

Apart from its later institutionalization, another crucial factor affecting the limited use of political science knowledge in Spain is the actual size of the discipline. In 2015, undergraduates studying for political science degrees in Spanish universities numbered 13,234. The equivalent numbers for those doing law and economics degrees and business studies degrees were, respectively, 110,625 and 183,338 (Jerez \& Luque, 2016: 187). These figures give an idea of the very limited size of the political science academic community compared to those of neighbouring disciplines. ${ }^{5}$

There are several possible consequences of this comparatively small political science community. First, in a scenario of growing demand for political science knowledge, it is most likely that such demand will not be met, and so knowledge consumers will have recourse to other sources. Secondly, size interacts with the above-mentioned advantage of more established disciplines, further reinforcing the 'Matthew effect' (Merton, 1968) favouring their advisory role vis-à-vis political science. This is related to the mechanism by which academic knowledge is usually passed on to the political decision-makers and other parties concerned by the political process. This mechanism involves other actors acting as brokers between knowledge producers (academics) and knowledge consumers (policy

\footnotetext{
${ }^{4}$ The abovementioned creation of the AEVAL is an example of this. The members of the consultation committee in charge of its creation with an economics background numbered twelve, compared to only four political scientists.

${ }^{5}$ Jerez and Luque (2016: 188) also offer comparative data about size, albeit limited to the number of associate and full professors in public universities. In 2014, that number stood at 175. The equivalent figures for the fields of constitutional law, applied economics and sociology were 248,1060 and 425 , respectively.
} 
makers or policy stakeholders) (Craft \& Howlett, 2012; Sundquist, 1978). People in government, public administration or stakeholder organizations are likely to play such a role, promoting the use of knowledge based on their own academic or professional background. Therefore, in the case of political science, the comparatively limited number of politicians, senior civil servants, organization executives and advisors who have studied political science is likely to negatively affect the possibility of political science knowledge being used.

This is not to say that political science academics have not been favoured by certain conditions. For example, the territorial advancement of political science-which is now taught at university in nine of the seventeen comunidades autónomas (Jerez \& Luque, 2016)—increases the likelihood that political scientists will develop their advisory skills through contact with subnational authorities and actors. Furthermore, certain favourable niches for political scientists are present in the policy advisory system: for example, specific public advisory bodies (OECD, 2017) exist within national and regional administrations, and even in local government. These bodies mostly deal with three fundamental questions: institutional and constitutional reform, public opinion research, and public administration modernization and reform. ${ }^{6}$ Academic political scientists are usually found within the staff of these bodies, recruited either on an ad-hoc or a regular basis, although these organisations are also populated by scholars from neighbouring disciplines.

Another niche for political scientists in Spain are think tanks. These may be divided into two groups. The first group comprises generalist think tanks covering a wide range of topics and may employ (as staff members or on an ad hoc basis) political scientists alongside members of other academic disciplines. The most well-known examples of such think tanks are

\footnotetext{
${ }^{6}$ Examples at national and regional levels include 1) Political and institutional reform: a) at the national level: Centro de Estudios Politicos y Constitucionales (CEPC, Centre for Political and Constitutional Studies); at the regional level: Instituto de Estudios de Autogobierno (IEA, Institute for Self-government Studies, Catalonia); 2) Public opinion research: a) at the national level: Centro de Investigaciones Sociológicas (CIS, Centre for Sociological Research); b) at the regional level: Centre d'Estudis d'Opinió (CEO, Centre for Opinion Studies, Catalonia); 3 ) public administration modernization and reform: a) at the national level: Instituto Nacional de Administración Pública (INAP, National Institute for Public Administration); b) at the regional level: Instituto Andaluz de Administración Pública (IAAP, Andalusian Institute for Public Administration, Andalusia), Escola d'Administració Pública de Catalunya (EAPC, Catalan School of Public Administration, Catalonia).
} 
close to one of the country's major political parties. This is the case of two progressive foundations, Alternativas (Alternatives) and Sistema (the System Foundation), linked to the Socialist Party (PSOE). In turn, the conservative FAES (Fundación para el Análisis y los Estudios SocialesFoundation for Social Analysis and Studies) is a well-known think tank with strong ties to the Popular Party (PP). Other think tanks where political scientists can be found offering their advisory services specialise in specific policy areas, particularly international relations - as is the case of the Real Instituto Elcano (Elcano Royal Institute) and that of the Barcelona Centre for International Affairs (CIDOB).

Finally, the presence of academic political scientists in the advisory system depends on factors within the discipline. These are of two types. On the one hand, the presence of incentives (positive or negative) entice academic political scientists to be proactive in engaging in policy or political advice activities. Spain is a country where prospective research impact and knowledge transfer are officially taken into consideration when assessing bids for research funding (Bandola-Gill et al., 2021) although the posthoc evaluation of individual contributions to knowledge transfer is in its early stages and is far from being formalized. ${ }^{7}$ Policy advisory activities may therefore not be very appealing to those political scientists focusing on the advancement of their academic careers. On the other hand, the involvement of academic political scientists in advisory activities might be conditioned by the normative orientation of the individuals concerned, reflecting their different ideas of the roles that academic political scientists should play.

This general review of the opportunities and limits affecting the engagement of Spanish political scientists in advisory activities with social and political actors provides the background for the empirical analysis of such involvement to be conducted in the following sections.

\subsection{The Advisory Activities of Spanish Political Scientists: Research Questions and Hypotheses}

There are two main research questions guiding the rest of the chapter. The first question is a descriptive one, and it refers to the prevalence and characteristics of advisory activities among Spanish academic political

\footnotetext{
${ }^{7}$ The first national call for the assessment of individuals' knowledge transfer across 6-year periods (the so-called sexenios de transferencia) dates back to 2018.
} 
scientists. The empirical analysis will focus on the types of advice provided and the frequency of engagement in those activities, in order to identify the distribution of Spanish political scientists in terms of the four advisory roles defined in Chap. 2 of this volume, namely: the pure academic (no engagement in advice activities); the expert (involved in purely technical advice activities, without providing value judgements); the opinionator (providing expert advice but also offering value judgements when doing so) and finally, the public intellectual (individuals with the broadest repertoire of advisory activities, including value judgements, and a very high level of engagement).

In addition, the description of the policy advisory patterns of Spanish political scientists will focus on the government levels where advice is provided, the main areas and recipients of advice and the channels through which advice is provided. The operationalization of these variables is presented in the following section.

In addition, the context of policy advice described in the previous section throws up a number of hypotheses regarding descriptive patterns in Spanish political scientists' advisory activities. Firstly, given the multilevel nature of the Spanish policy advisory system and the territorial spread of academic political science, advisory activities at the subnational level are expected to be more frequently engaged in than those at the national or supranational levels (Hypothesis 1). Secondly, regarding the areas of advice, given the competitive disadvantage of political science compared to other disciplines within the advisory system, Spanish political scientists' advisory activities are expected to be significantly more frequent in those policy areas where advice requires core disciplinary political scientific knowledgenamely, the area of government and public administration organization and that of electoral reform (Hypothesis 2).

The second research question in this chapter focuses on the factors explaining academic political scientists' involvement in political or policy advice; that is, it centres on the differences between those who are involved in some form of advisory activity and those who are not, and on the intensity of such activity. In this respect, I will focus on a number of demand and supply factors. With regard to demand, the previous section has shown that political scientists have more opportunities to provide advice when the knowledge they produce better fits the demand of political agents, as in the case of electoral behaviour, territorial or institutional reform, and public administration modernization and reform. Furthermore, it is plausible that policy specialists are more likely to be in demand as advisors than 
non-policy specialists are. Therefore, the expectation is that political scientists with those types of specialisation are more likely to participate in advisory activities than those without them (Hypothesis 3).

Regarding the explanatory factors on the supply side, I shall consider two types of factor. Firstly, there is the impact of internalized professional norms. Engagement in advisory activities may obey a 'logic of appropriateness' (March \& Olsen, 1984) and so the decision to engage in such activities may depend on the political scientists' perception of it as part of what they should do. In this respect, engagement in policy advice is expected to be more frequent among those who consider it part of their professional duties (Hypothesis 4).

Secondly, there is the influence that incentives have on the supply of advisory services. Since the survey data I use (see below) do not include any question concerning the influence of incentives that could be used in the explanatory analysis, ${ }^{8} \mathrm{I}$ will resort to using the level of progression in one's academic career as a proxy. Since, as manifested in the previous section, the incentives to getting involved in advisory activities are very limited in Spain, it is expected that, since those individuals who are still at a developmental stage of their careers, and thus are more focused on activities that could contribute positively to such development (i.e. publishingoriented research, management tasks), they are less likely to be involved in advisory activities (Hypothesis 5). In this respect, since highly intensive publishing-oriented research is likely to consume much of such individuals' time, it is also likely that those involved in highly intensive research work are less inclined to engage in policy advisory tasks (Hypothesis 5b).

However, it is necessary to consider the demand aspect of political scientists' career stage. Thus, the likelihood of political scientists at an advanced stage in their careers being asked to act as advisors, may be greater simply because they also possess greater expertise, gained down the years. In order to separate these two effects, I propose an interaction. Therefore, following the previous reasoning, it is also likely that advancedstage political scientists with lower levels of specialisation are less in demand than those with higher levels of specialisation (Hypothesis 6). ${ }^{9}$

\footnotetext{
${ }^{8}$ The questions of this type were asked only to those respondents who indicated they participated in advisory activities, but not to those who did not.

${ }^{9}$ This hypothesis can be also formulated focusing on early-stage researchers: early-stage political scientists with higher levels of specialisation are more demanded than those showing lower levels of specialisation.
} 


\subsection{Data And Methods}

In order to test the hypotheses presented in the previous section, I am going to use the data from the ProSEPS survey of political scientists in Europe. The total size of the sample in Spain was 140, which represents a response rate of $30 \%$ of the population of political scientists working in Spain who were invited to participate in the survey. Women are slightly under-represented in the sample $(33 \%$, compared to $35 \%$ in the population).

The variables used in the descriptive analysis (see next section) are operationalized as follows. The four types of advisory role (pure academic, expert, opinionator and public intellectual) are constructed just as they are in the other chapters of this book, that is, by combining the types of advice provided over the last three years (whether they imply providing value judgements and normative arguments, or not), the frequency of participation in advisory activities over the last three years and the scope or range of advice (the number of different types of advisory activity an individual has engaged in over the period in question) (see Chap. 2 in this volume for more details on the construction of the types of advisory role).

Regarding the other variables, the levels of government considered are subnational, national and EU/international. For the areas of expertise, the list is based on the coding of policy areas used by the comparative agendas project (Green-Pedersen \& Walgrave, 2014). In turn, recipients of advice are subdivided into six main arenas, based on the location of the advice producers-recipients concerned (see Blum \& Brans, 2017): the inner governmental arena (including executive politicians, civil servants, members of parliament), public advisory bodies (which may include both governmental and non-governmental actors), political party organizations, think tanks, interest groups and other private associations, and the international arena. Finally, the channels of advice are subdivided into three groups: exclusively formal, exclusively informal and mixed.

With regard to the variables considered in the explanatory analysis, the focus is on explaining why individuals engage in advisory activities, and on the intensity of such engagement, irrespective of the type of advice. Consequently, the dependent variable (frequency of advice) is an ordinal one, coding three possible situations: individuals who have not provided any kind of advice over the last three years; those providing some kind of advice, but less than once a month, and those who have provided advice more frequently than once a month during that same period. In order to 
increase the number of observations, missing values have been considered as cases of no advice given.

Regarding the independent variables, the 'type of specialisation' variable represents the field of specialisation characterizing the respondent's most advanced university qualification. The initial categories in the ProSEPS survey totalled fourteen (plus one 'Other' category), and individuals could choose a maximum of three such categories. Therefore, four variables have been created, the first three as proxies for areas of higher demand for political scientific advice: 1) expertise in the field of public administration or political institutions (including local government); 2) specialisation in electoral behaviour, including expertise in political communication; 3 ) public policy expertise (specialisation in the policy process or specific policy sectors). A categorical variable was then created that measures different levels of specialisation in 'marketable' political science knowledge areas, and this takes the following values: 0 ('No specialisation'), 1 ('Specialisation in one of the three areas'), and 2 ('Specialisation in two or all of the three areas').

In order to measure whether engagement in policy advisory activities obeys a 'logic of appropriateness' (Hypothesis 4), I will use the level of agreement of respondents to the ProSEPS survey with a normative statement concerning a general professional norm commanding such engagement ('political scientists should become involved in policy making'). To test the influence of epistemic norms (Hypothesis 4b), I use the level of agreement with another normative statement ('Political scientists should provide evidence-based knowledge and expertise outside of academia, but not be directly involved in policy-making'). Although the second part of this sentence ('but not be directly involved in policy-making') may somewhat distort the relationship with the corresponding dependent variable (see above), the expression is ambiguous enough to not preclude the toleration and participation of the respondent in such advisory activities. Both normative variables have been recoded to a binary form (agree vs. disagree).

Hypothesis 5 refers to the impact that career stage has on the likelihood of engagement in advisory tasks, from a supply-side perspective. This variable is operationalized using age as a proxy-since younger individuals are more likely to be at early stages of their careers. ${ }^{10}$ Furthermore, the

\footnotetext{
${ }^{10}$ An alternative variable accounting for the stage of an academic's career, which is also provided in the ProSEPS survey dataset, is whether respondents have a permanent or fixed-
} 
possible negative influence of publication-oriented research activities (Hypothesis $5 \mathrm{~b}$ ) is measured by a variable representing the international publication record of the respondent. ${ }^{11}$ Finally, the joint influence of career stage and level of specialisation on the likelihood of engaging in advisory activities is measured through an interaction term combining age and levels of specialisation.

With regard to the techniques of analysis adopted in the explanatory section, given the nature of the two dependent variables, I use ordered logistic regression for the model explaining the frequency of advice and multinomial logistic regression for the model of the types of advice.

\subsection{Descriptive Analysis}

With regard to the distribution of different advisory roles among political scientists in Spain, Table 12.1 shows that a great majority of those who responded to the ProSEPS survey (78.6\%) have provided some form of political or policy advice over the last three years. Of these, a great majority ( $42.1 \%$ of the total) are of the 'opinionator' type (i.e. political scientists providing both expert knowledge and normative arguments), while a small minority (5\%) show high levels of engagement in advisory tasks, in terms of frequency (at least once a month) and scope (four or more types of advice, including the provision of value judgements). In any case, the distribution does not significantly differ from the general pattern detected in the ProSEPS survey.

With respect to the recipients of advice (Table 12.2), almost $70 \%$ of the respondents who were engaged in advisory tasks claim to have engaged with representatives at inner government level, either executive politicians or civil servants. More specifically, contacts were much more frequent with

term contract. However, this variable may mask the incentives that individuals with permanent contracts may have to advance their careers (for instance, promotion from associate professor to full professor).

${ }^{11}$ This variable is constructed as the addition of three variables: the number of publications in international peer-reviewed journals; the chapters in edited books published by international publishing houses and the number of monographic studies published by international publishing houses. Each of these variables is measured nominally at three levels $(1=$ 'nothing published in that category', 2 = 'one or two publications in that category' and $3=$ 'three or more publications'). I have recoded them as quantitative variables, where 'no publications' is given a score of 0 , 'one or two' a score of 1.5 and 'three or more' a score of 3 . I then added the scores for the three variables to obtain the variable used in the analysis. 
Table 12.1 Proportion of ideal types of policy advisory roles-Spain

\begin{tabular}{lccc}
\hline & Total N (Spain) & Percentage (Spain) & Percentage (overall sample) \\
\hline Pure academic & 30 & $21.4 \%$ & $20.3 \%$ \\
Expert & 44 & $31.4 \%$ & $26.6 \%$ \\
Opinionator & 59 & $42.1 \%$ & $48.7 \%$ \\
Public intellectual & 7 & $5.0 \%$ & $4.4 \%$ \\
\hline
\end{tabular}

Note: Types operationalized on the basis of content of advice and frequency. See Chap. 3.

Source: ProSEPS survey data.

Table 12.2 Recipients of advice \% (total and by types of advisory role)-Spain

\begin{tabular}{|c|c|c|c|c|c|}
\hline $\begin{array}{l}\text { Inner } \\
\text { government }\end{array}$ & $\begin{array}{l}\text { Parties and } \\
\text { parliament }\end{array}$ & $\begin{array}{l}\text { Advisory } \\
\text { bodies }\end{array}$ & $\begin{array}{l}\text { Think } \\
\text { tanks }\end{array}$ & $\begin{array}{l}\text { Interest } \\
\text { groups } \\
\text { and } \\
\text { NGOs }\end{array}$ & $\begin{array}{l}\text { International } \\
\text { organizations }\end{array}$ \\
\hline
\end{tabular}

\begin{tabular}{lrrrrrr}
\hline Expert & $50.0 \%$ & $40.9 \%$ & $15.9 \%$ & $34.1 \%$ & $40.9 \%$ & $34.1 \%$ \\
Opinionator & $79.7 \%$ & $62.7 \%$ & $16.9 \%$ & $57.6 \%$ & $54.2 \%$ & $32.2 \%$ \\
$\begin{array}{l}\text { Public } \\
\text { intelectual }\end{array}$ & $\mathbf{1 0 0 . 0 \%}$ & $\mathbf{7 1 . 4 \%}$ & $\mathbf{1 4 . 3} \%$ & $\mathbf{8 5 . 7 \%}$ & $\mathbf{8 5 . 7 \%}$ & $\mathbf{2 8 . 6 \%}$ \\
Total & $69.1 \%$ & $54.5 \%$ & $16.4 \%$ & $50.0 \%$ & $50.9 \%$ & $32.7 \%$
\end{tabular}

Note: Percentages computed with respect to those respondents who claimed to have been engaged in advisory activities during the last three years $(\mathrm{N}=110)$. Question: 'With which actors did you engage in knowledge exchange, advisory or consulting activities during the last three years?'

Source: ProSEPS survey data.

the former category: $58.2 \%$ acknowledged having had this type of contact, compared with $40 \%$ who claim to have advised civil servants at some point in time, this figure being significantly below the average in the ProSEPS sample (52.6\%). Moreover, over half of those who provided advice did so for political parties or legislators, think tanks and interest groups, or other non-governmental organizations (NGOs). More specifically, the level of engagement with corporate interest groups (10\%) was significantly below the ProSEPS survey sample (25.4\%). Also, a significant proportion $(32.7 \%)$ also engaged with international organizations, albeit less frequently. Finally, only a small minority (16.4\%) advised public advisory bodies. Most of these patterns coincide with the general ones found in the ProSEPS survey, with the exception of contacts with interest groups or other NGOs 
and public advisory bodies, which political scientists in Spain tend to be significantly less involved with.

Table 12.2 also reveals the differences between the diverse types of advisor. In general, political scientists whose advisory activity is limited to providing expert knowledge are much less active in most of the arenasthe only exception being that of international organizations. Advisory activity increases in the cases of opinionators and, above all, public intellectuals. Regarding the latter category, this elite group within Spain's political science community is significantly engaged in advisory tasks with both public actors (particularly those in government) and private ones. On the other hand, they are less internationally oriented than the members of the other two categories - although the differences are minimum and not statistically significant.

This descriptive analysis also focuses on the degree of formality of contacts between political scientists and the recipients of their advice. Formal and informal modes of advice provision are evenly distributed among political scientists in Spain - a general pattern that also holds for the entire sample in the ProSEPS survey. Regarding the different types of advisory role, there is barely any difference between experts and opinionators. However, in the case of public intellectuals, formal aspects seem to be more prevalent (about $42 \%$ claim that the advice is mostly formal, while this figure in the other categories is less than $18 \%$ ).

Regarding the government level at which advice is provided (Table 12.3), two-thirds (exactly 67.6\%) of those engaged in advisory activities addressed actors at the subnational level (regional or local), and $37 \%$ provided advice exclusively at this level. The corresponding figures for the national level are 47.2 and $12 \%$, respectively. The proportion of those engaging with international actors is lower, though not negligible- $31.5 \%$ of respondents, although only $4.6 \%$ operate exclusively at the international level. Looking at the uniqueness or mix of levels of engagement in advisory activities, the sample is almost evenly divided, with 53.7\% dealing exclusively with one level, while the rest provided advice to two different levels over the three years prior to the survey fieldwork.

Compared with the other countries covered by the ProSEPS survey, the percentage of political scientists in Spain who exclusively engage with actors at the subnational level, or who do so at both subnational and international levels, are significantly higher than average. This pattern is found in two other countries only, Germany and Russia, both of which are federal states. 
Table 12.3 Governance levels of advice (total \% and by types of advisory role)-Spain

\begin{tabular}{lcccccc}
\hline & $\begin{array}{c}\text { Only } \\
\text { subnational }\end{array}$ & $\begin{array}{c}\text { Only } \\
\text { national }\end{array}$ & $\begin{array}{c}\text { Subnational Subnational } \\
\text { er national }\end{array}$ & $\begin{array}{c}\text { National } \\
\text { international } \\
\text { international }\end{array}$ & $\begin{array}{c}\text { Only } \\
\text { international }\end{array}$ \\
\hline $\begin{array}{l}\text { Expert } \\
\begin{array}{l}\text { Opinionator } \\
\text { Public }\end{array}\end{array}$ & $25.0 \%$ & $13.6 \%$ & $22.7 \%$ & $11.4 \%$ & $18.2 \%$ & $9.1 \%$ \\
$\begin{array}{l}\text { intelectual } \\
\text { Total }\end{array}$ & $28.6 \%$ & $14.3 \%$ & $57.1 \%$ & $12.3 \%$ & $15.8 \%$ & $1.8 \%$ \\
\hline
\end{tabular}

Note: Percentages computed with respect to those respondents who claimed to have been engaged in advisory activities during the last three years $(\mathrm{N}=108)$. Question: 'At which level of governance did you engage most frequently in policy advice or consulting activities during the last three years?'

Source: ProSEPS survey data.

As regards the different types of advisory role, Table 12.3 also shows that the proportion of opinionators dealing exclusively with subnational actors is significantly higher $(47.4 \%)$ than it is for the other two categories of advisor. It is also remarkable to see that international actors do not receive the advice of public intellectuals at all, despite the greater frequency and scope of said intellectuals' advisory activities.

In sum, the patterns shown in Table 12.3 confirm the validity of Hypothesis 1, since they provide evidence of the influence of the politically decentralized structure of the Spanish state on the advisory patterns of academic political scientists in Spain, whose greatest opportunities for providing advice exist at the subnational (mainly regional) governance level.

The second descriptive hypothesis presented above also finds confirmation in the data (Table 12.4). The main area in which Spanish political scientists provide advice is that of government and public administration organization, and electoral reform. The percentage of those providing advice regarding this area $(53.6 \%)$ is much higher than that of the other policy areas targeted by political scientists as policy advisors: social and welfare policies $(24.5 \%)$, civil rights and gender $(23.6 \%)$, EU and international affairs $(21.8 \%)$ and immigration $(14.5 \%)$. It is remarkable that the two most important sectors (government and social policies) attract significantly more advice from political scientists in Spain than in the other countries covered by the ProSEPS survey (the respective averages, 
Table 12.4 Policy area of advice—Spain

\begin{tabular}{lc}
\hline & Percentage \\
\hline Government and public administration organization, electoral & $53.6 \%$ \\
reforms & \\
Social welfare & $24.5 \%$ \\
Civil rights, political rights, gender issues & $23.6 \%$ \\
International affairs, development aid, EU & $21.8 \%$ \\
Immigration, integration, ethnic minorities & $14.5 \%$ \\
Education & $8.2 \%$ \\
Public works, urban planning & $5.5 \%$ \\
Other (*) & $38.2 \%$ \\
\hline
\end{tabular}

Note: Percentages computed with respect to those respondents who claimed to have been engaged in advisory activities during the last three years $(\mathrm{N}=110)$. The list of categories has been adapted from the policy areas list of the Comparative Agendas Project. Question: 'With which substantive policy areas is your advice concerned?' (*) The 'Other' category comprises the following areas: Technology (including telecommunications) $(5.5 \%)$, crime, law and order $(4.5 \%)$, macroeconomics, monetary policy, industry policy $(3.6 \%)$, labour $(3.6 \%)$, environment $(3.6 \%)$, culture $(3.6 \%)$, transportation $(2.7 \%)$, defence $(2.7 \%)$, housing $(1.8 \%)$, health $(0.9 \%)$, domestic trade, commerce, financial sector $(0.9 \%)$, agriculture, food policy $(0.0 \%)$, energy $(0.0 \%)$, foreign trade $(0.0 \%)$, other substantive policy areas (not in the previous categories) $(4.6 \%)$.

Source: ProSEPS survey data.

excluding Spain, are 46.4 and 11.5\%). In contrast, policy advice offered by political scientists is underdeveloped in other areas, such as energy $(0 \%)$, defence $(2.7 \%)$ and, in particular, EU and international affairs (21.8\% compared to the average in other countries of $36.8 \%$ ).

In any case, in keeping with Hypothesis 2 , it would seem that demand for political scientists' advice is higher in the area where the discipline has a high level of 'ownership' over the knowledge at stake.

\subsection{EXPLANATORY ANALYSIS}

The remaining explanatory hypotheses set out above are tested in this section. Given the low number of observations, models are restricted to the basic variables - those testing the corresponding hypotheses plus a control variable (gender). The main descriptives of the variables in the analyses are shown in Table 12.5 .

The models in Table 12.6 test the hypotheses relating to the frequency of advice provision. For the sake of the interpretability of the ordered logit results, these are presented in the 'odds ratio' form. Both hypotheses 4 
and 5 are confirmed. First, participation in advisory activities in Spain is significantly related to professional normative beliefs. Thus, the probability of providing advice against not providing it multiplies by about 1.8 when the respondent agrees with the statement 'political scientists should become involved in policy making'. The same applies to the probability of being very frequently involved in advisory tasks (at least once a month) compared with not being involved at all, or doing it only sporadically.

Secondly, advice practices seem to be influenced by the stage of an academic's career development. The significant influence of the age variable over the frequency of advice (though the significance level is at $p<0.1$ ) in Model 1 suggests that individuals at early stages of their careers are less likely to engage in policy advisory activities (the likelihood increases about $8 \%$ for each additional year).

However, the effect of age must be evaluated jointly with that of the level of specialisation. Model 2 points to the relationship between these two variables. As mentioned above, it is likely that these variables interact and that the effect of career stage is modulated by the degree of expertise. This interactive relationship was the target of Hypothesis 6, which finds confirmation in the model.

A clearer interpretation of how both of the aforementioned variables condition one another is given in Fig. 12.1. The different graphs for marginal probabilities suggest four types of pattern, each with different explanations. On the one hand, there is a pattern of higher probability of participating in advisory activities as individuals develop their careers, which could reflect some kind of seniority effect. It is most evident when respondents are not specialised in any of the more 'marketable' political science areas (upper left panel), and when higher levels of participation are contrasted with not participating at all. Therefore, the expected

Table 12.5 Variables in the analysis and descriptives-Spain

\begin{tabular}{lrrrrr}
\hline Variable & $N$ & Mean & Std. Dev. & Min & Max \\
\hline Frequency of advice & 123 & 0.98 & 0.66 & 0 & 2 \\
Degree of specialisation & 123 & 0.92 & 0.73 & 0 & 2 \\
General professional norm & 123 & 2.37 & 0.68 & 0 & 3 \\
Age & 123 & 48.40 & 9.78 & 30 & 75 \\
International publishing record & 123 & 3.9 & 2.63 & 0 & 9 \\
Male & 123 & 0.61 & 0.49 & 0 & 1 \\
\hline
\end{tabular}

Source: ProSEPS survey data. 
Table 12.6 Explaining frequency of political advice among political scientists-Spain

\begin{tabular}{lll}
\hline Variables & Model 1 & Model 2 \\
\hline Level of specialisation (medium) & 0.88 & 22.43 \\
& $(0.374)$ & $(51.493)$ \\
Level of specialisation (high) & 1.36 & $148.15^{*}$ \\
& $(0.618)$ & $(299.260)$ \\
General professional norm & $1.86^{*}$ & $1.84^{*}$ \\
& $(0.496)$ & $(0.504)$ \\
Age & $1.03+$ & $1.08^{* * *}$ \\
& $(0.020)$ & $(0.027)$ \\
Age*Medium specialisation & & 0.94 \\
& & $(0.045)$ \\
Age*High specialisation & & $0.91^{*}$ \\
& & $(0.037)$ \\
International publishing record & 1.08 & 1.11 \\
& $(0.077)$ & $(0.080)$ \\
Male & 1.60 & 1.35 \\
& $(0.688)$ & $(0.618)$ \\
Observations & 123 & 123 \\
Pseudo R-squared & 0.05 & 0.07 \\
LR Chi2 & 12.81 & 24.35 \\
Prob>Chi2 & 0.05 & 0.00 \\
& &
\end{tabular}

Note: Figures represent odds ratio for ordered logistic regression. Robust standard errors in parentheses. The dependent variable is the frequency of advice: 0 (reference) $=$ No advice; $1=$ less than once every month; 2 = at least once or more every month. The reference category for Level of specialisation is 'No specialisation', and for Male is 'Female and gender not declared'.

*** $\mathrm{p}<0.005,{ }^{* *} \mathrm{p}<0.01,{ }^{*} \mathrm{p}<0.05,+\mathrm{p}<0.1$.

probability of not participating greatly decreases with age, while that of intensive involvement (providing advice at least once a month) increases as a political scientist's career develops. The impact of this seniority effect is expected to diminish as specialisation increases (upper right panel).

This seniority effect could be also inferred from the observation of those sporadically participating in advisory activities involving no specialisation (upper left panel), although the likelihood of participation decreases towards the end of a person's career-probably an additional manifestation of this seniority effect. Nevertheless, this pattern could be also seen as a result of a career cycle effect, as the probability of participation increases until respondents reach middle age-coinciding with the period in which they may be building their academic careers-while such probability 

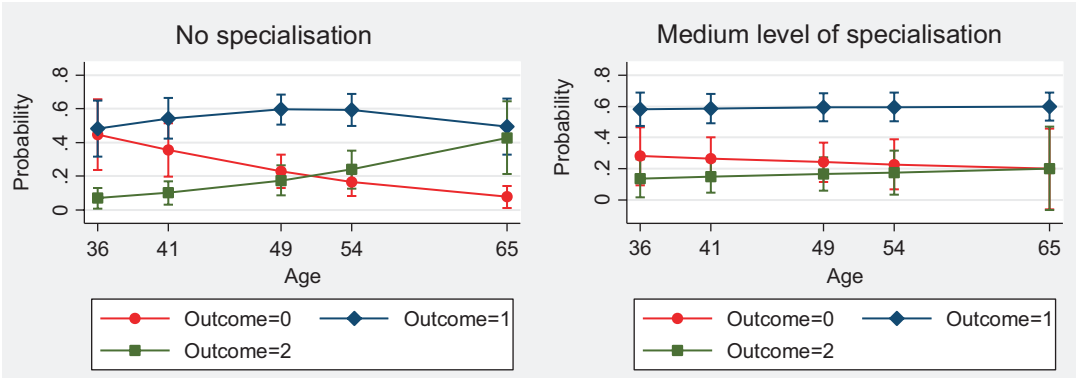

Highest level of specialisation

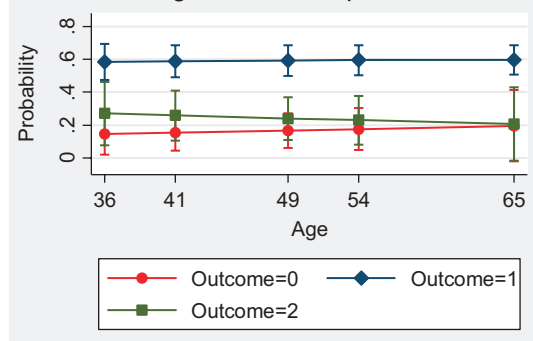

Fig. 12.1 Joint effect of age and level of specialisation-Spain. Note: Marginal predicted probabilities, with $95 \%$ confidence intervals, based on the results of Model 2 in Table 12.6. The values of the outcome variable (frequency of advice) are $0=$ No advice during the last three years; $1=$ Advice less than once a month; $2=$ Advice at least once a month. Levels of specialisation refers to specialisation (at the highest university degree) in one or more of the following areas (see text for details): 1) public administration or political institutions (including local government); 2) specialisation in electoral behaviour, also including expertise in political communication; 3 ) public policy expertise (specialisation on the policy process or on specific policy sectors). Age values are set at percentiles 10, 25, 50, 75, and 90.

stabilizes and decreases as they approach retirement age. In any case, the existing evidence is insufficient to differentiate between both types of pattern.

The lower left panel shows a third type of pattern-a kind of inverted version of the seniority effect. Thus, at high levels of specialisation, the likelihood of very frequent participation in advisory activities decreases with age, while that of not participating at all increases. The mechanism accounting for this pattern may be linked to a life-cycle effect; however, this explanation is inconsistent with the seniority effect found for the other 
levels of specialisation. That is, if those without any 'marketable' skill are more likely to become highly active in advisory tasks as they get older, why does the same thing not happen in the case of the highly specialised political scientists? A possible explanation for this pattern could be some sort of renewal or generational substitution effect, where older specialists are replaced by younger ones. This explanation makes sense from the perspective of advice recipients, since they may well believe that younger experts are more likely to possess state-of-the-art methods, skills and knowledge.

There is a final pattern of interaction affecting those who sporadically participate in advisory tasks and present average or high levels of specialisation. In these cases, Figure 12.1 shows that the likelihood of such involvement does not vary with age.

Finally, I should point out that Hypothesis $5 \mathrm{~b}$ is not corroborated by the data. Thus, the degree of involvement in academic-oriented research activities does not affect the probability of engagement in advisory activities.

\subsection{Conclusions}

This chapter has shown that most political scientists in Spain are involved to some extent in political or policy advisory activities. This seems to be favoured by the decentralized structure of the Spanish state, which multiplies the opportunities for engagement, particularly in the public sector. Moreover, advice is more frequently provided in those areas where political science has 'issue ownership' (government organization and electoral reform) compared to other social science disciplines. In contrast, although advice on specific policies is not totally absent, it is usually less frequent than in other countries (the one exception being advice on welfare policies).

In addition to these demand-side factors, the engagement of political scientists in political and policy advisory activities is also dependent on the supply side, and in particular on political scientists' propensities, qualifications and availability. Therefore, the chapter has demonstrated how internalized professional norms, expertise and seniority (this being associated with tenure) favour the participation of political scientists in such advisory activities.

These findings also offer some clues to ways in which the scope and relevance of political science to political and policy processes can be further broadened. On the one hand, the analysis has shown that in Spain 
there is still room for expansion in certain specific policy areas in which political scientist in other countries play a more prominent role. Since relevance is immediately related to the ability to generate specialised knowledge in those problem areas where political science has a competitive advantage over other disciplines, any expansion into specific policy areas where political scientists in other European countries play a greater role (areas such as international relations, energy and defence) would probably result in direct competition with other, better equipped or more established disciplines (mainly international law and economics).

On the other hand, political scientists in Spain can still expand their advisory clientele, particularly in the public administration sphere where their influence is still limited compared to that witnessed in other countries. This is partially due to the propensity in Spain's public administration to favour internal over external advice. However, it also relates to the aforementioned need for greater specialisation in specific policy areas (e.g. in the areas of evaluation and management processes) in addition to those where political science potentially possesses a competitive edge, since this is the kind of knowledge that mostly interests government bureaucrats.

Therefore, the expansion of the advisory importance of political science in Spain would probably entail political scientists fostering further policy specialisation, which would likely imply introducing epistemic elements blurring the demarcation between political science and neighbouring disciplines. This is not a major problem for political science, which has always been ready to import tools from other disciplines. The question here is whether such an interdisciplinary transformation would allow political scientists to maintain the identity of the discipline and offer their own approach to the problems and issues for which their advice is sought.

\section{REFERENCES}

Alba, C. R., \& Navarro, C. (2011). Administrative Tradition and Reforms in Spain: Adaptation Versus Innovation. Public Administration, 89(3), 783-800. https://doi.org/10.1111/j.1467-9299.2010.01886.x

ATCEE. (2020). 'Historia del cuerpo', viewed 14 February 2020, https://atcee. es/el-cuerpo/historia-del-cuerpo.

Bandola-Gill, J., Flinders, M., \& Brans, M. (2021). Incentives for Impact: Relevance Regimes through a Cross-National Perspective. In R. Eisfeld \& M. Flinders (Eds.), Political Science in the Shadow of the State: Research, Relevance, Deference. Palgrave Macmillan. 
Blum, S., \& Brans, M. (2017). Academic policy analysis and research utilization for policymaking. In M. Brans, I. Geva-May, \& M. Howlett (Eds.), Routledge Handbook of Comparative Policy Analysis (pp. 341-359). Routledge.

Craft, J., \& Howlett, M. (2012). Policy formulation, governance shifts and policy influence : location and content in policy advisory systems. Journal of Public Policy, 32(2), 79-98. https://doi.org/10.1017/S0143814X12000049

Easton, D. (1969). The New Revolution in Political Science. American Political Science Review, 63(4), 1051-1061.

Flinders, M. (2013). The Tyranny of Relevance and the Art of Translation. Political Studies Review, 11(2), 149-167. https://doi. org/10.1111/1478-9302.12011

Flyvbjerg, B. (2001). Making Social Science Matter: Why social inquiry fails and how it can succeed again. Cambridge University Press.

Flyvbjerg, B. (2006). A Perestroikan Straw Man Answers Back: David Laitin and Phronetic Political Science. In S. F. Schram \& B. Caterino (Eds.), Making Political Science Matter: Debating Knowledge, Research, and Method (pp. 56-85). New York University Press.

Flyvbjerg, B., Landman, T., \& Schram, S. (2012). Real Social Science: Applied Phronesis. Cambridge University Press.

Green-Pedersen, C., \& Walgrave, S. (Eds.). (2014). Agenda Setting, Policies and Political Systems: A Comparative Approach. The University of Chicago Press.

Jerez-Mir, M. (2010). The Institutionalization of Political Science: The Case of Spain. In G. Castro \& J. De Miguel (Eds.), Spain in América. The First Decade of The Prince of Asturias Chair in Spanish Studies at Georgetown University (pp. 281-329). Fundación ENDESA / Ministerio de Educación.

Jerez, M., \& Luque, J. (2016). Treinta años de ciencia política en España: Profesionalización, expansión y ajuste. Revista Espanola de Ciencia Politica, 40, 179-215. https://doi.org/10.1234/recp.n40.2016.pp\%p

Laitin, D. D. (2003). The Perestroikan challenge to social science. Politics and Society, 31(1), 163-184. https://doi.org/10.1177/0032329202250167

Magone, J. M. (2008). Contemporary Spanish Politics (2nd ed.). Routledge.

March, J. G., \& Olsen, J. P. (1984). The New Institutionalism: Organizational Factors in Political Life. The American Political Science Review, 78(3), 734-749.

Martín Rodríguez, M. (1989). La institucionalización de los estudios de economía política en la Universidad española (1776-1857). Revista de Historia Económica, 2, 89-92.

Merton, R. K. (1968). The Matthew Effect in Science. Science, 159(3810), 56-63. Molins, J. M., \& Medina, I. (2019). Los grupos de interés. In J. Montabes \& A. Martínez (Eds.), Gobierno y politica en España (pp. 615-645). Tirant Lo Blanch.

Monroe, K. R. (Ed.). (2005). Perestroika! The Raucous Rebellion in Political Science. Yale University Press. 
Montabes, J., \& Martínez, A. (eds.) (2019). Gobierno y política en España. Valencia Tirant Lo Blanch.

Muro, D., \& Lago, I. (Eds.). (2020). The Oxford Handbook of Spanish Politics. Oxford University Press.

OECD. (2015). Spain: From Administrative Reform to Continuous Improvement. OECD.

OECD. (2017). Policy Advisory Systems: Supporting Good Governance and Sound Public Decision Making. OECD.

Ongaro, E. (2010). Public Management Reform and Modernization: Trajectories of Administrative Change in Italy, France, Greece, Portugal and Spain. Edward Elgar.

Ortega-Ruiz, M., Real-Dato, J., \& Jerez-Mir, M. (2021). Late but not least? Spanish political science struggle for internationalisation in the twenty-first century. European Political Science, 20(1), 159-182. https://doi.org/10.1057/ s41304-021-00315-z

Parrado, S. (2008). Failed policies but institutional innovation through " layering " and " diffusion" in Spanish central administration'. International Journal of Public Sector Management, 21(2), 230-252. https://doi. org/10.1108/09513550810855672

Real-Dato, J., \& Verzichelli, L. (2021). In search of relevance: European political scientists and the public sphere in critical times. European Political Science. Online first 10 June 2021. https://doi.org/10.1057/s41304-021-00335-9

Reniu, J. M. (Ed.). (2018). Sistema politico español. Huygens.

Ricci, D. M. (1984). The Tragedy of Political Science: Politics, Scholarship, and Democracy. Y. U. Press.

Schram, S. F., \& Caterino, B. (Eds.). (2006). Making Political Science Matter: Debating Knowledge, Research, and Method. New York University Press.

Stoker, G., Peters, B. G., \& Pierre, J. (Eds.). (2015). The Relevance of Political Science. Palgrave Macmillan.

Sundquist, J. L. (1978). Research Brokerage: The Weak Link. In L. E. Lynn Jr. (Ed.), Knowledge and Policy: the Uncertain Connection (pp. 126-144). National Academy of Sciences.

Weiss, C. (1977). Research for Policy's Sake: The Enlightenment Function of Social Research. Policy Analysis, 3(4), 531-545.

Weiss, C. H. (1980). Knowledge Creep and Decision Accretion. Knowledge: Creation, Diffusion, Utilization, 1(3), 381-404. 
Open Access This chapter is licensed under the terms of the Creative Commons Attribution 4.0 International License (http://creativecommons.org/licenses/ by $/ 4.0 /$ ), which permits use, sharing, adaptation, distribution and reproduction in any medium or format, as long as you give appropriate credit to the original author(s) and the source, provide a link to the Creative Commons licence and indicate if changes were made.

The images or other third party material in this chapter are included in the chapter's Creative Commons licence, unless indicated otherwise in a credit line to the material. If material is not included in the chapter's Creative Commons licence and your intended use is not permitted by statutory regulation or exceeds the permitted use, you will need to obtain permission directly from the copyright holder.

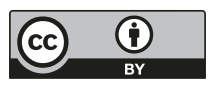

